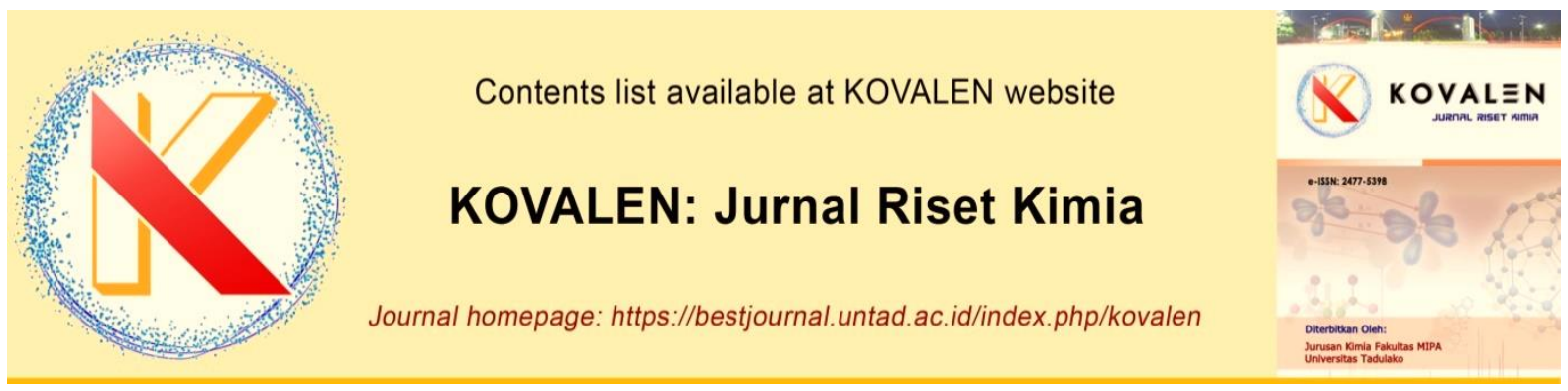

\title{
Uji Potensi Nefropati Diabetes Daun Sirih Merah (Piper croatum Ruiz \& Pav) pada Tikus Putih Jantan (Rattus norvegicus)
}

\section{[Potential Test of Diabetes Nefropative of Red Betel Leaf (Piper croatum Ruiz \& Pav) on Male White Rats (Rattus norvegicus)]}

\author{
Joni Tandi*, Rizaldy Lalu, Siti Nuraisyah, Magfirah,Yunlis Silintowe Kenta, \\ Ronaldy Nobertson
}

Program Studi S1 Farmasi, STIFA Pelita Mas Palu

${ }^{*}$ Corresponding author: Jonitandi757@yahoo.com

\begin{abstract}
This study aims to determine the type of secondary metabolite compounds in red betel leaf ethanol extract, the potential of red betel leaf ethanol extract on blood glucose, creatinine, and urea levels of male white rats induced by streptozotocin. This study used 30 white male rats which were divided into 6 groups: normal control, negative control, positive control, the dose of 150,250 , and $350 \mathrm{mg} / \mathrm{kg} \mathrm{BW}$. The showed that results ethanol extract of red betel leaves contained alkaloids, flavonoids, phenols, saponins, and tannins. Ethanol extract of red betel leaf at a dose of $150 \mathrm{mg} / \mathrm{kg} \mathrm{BW}$ is an effective dose in reducing levels glucose blood with an average value of decreased blood glucose levels of $238.25 \mathrm{mg} / \mathrm{dL}$, and has an effect on creatinine and ureum, with an average dose of $350 \mathrm{mg} / \mathrm{kg} \mathrm{BW}$ with a mean creatinine level of $0.64 \mathrm{mg} / \mathrm{dL}$ and mean ureum of $39.68 \mathrm{mg} / \mathrm{dL}$.
\end{abstract}

Keywords: Creatinine, ureum, red betel leaf, streptozotocin

ABSTRAK. Penelitian ini bertujuan untuk mengetahui jenis senyawa metabolit sekunder pada ekstrak etanol daun sirih merah, potensi ekstrak etanol daun sirih merah terhadap kadar glukosa darah, kreatinin dan ureum tikus putih jantan yang diinduksi streptozotocin. Penelitian ini menggunakan hewan uji tikus putih jantan sebanyak 30 ekor yang dibagi menjadi 6 kelompok yaitu kontrol normal, kontrol negatif, kontral positif, dosis 150, $250 \mathrm{dan} 350 \mathrm{mg} / \mathrm{kg}$ BB. Hasil penelitian menunjukan bahwa ekstrak etanol daun sirih merah mengandung senyawa alkaloid, flavonoid, fenol, saponin dan tanin. Ekstrak etanol daun sirih merah dosis $150 \mathrm{mg} / \mathrm{kgBB}$ merupakan dosis yang efektif dalam menurunkan kadar glukosa darah dengan nilai rata-rata penurunan kadar glukosa darah 238,25 mg/dL, dan memberikan efek terhadap kreatinin dan ureum, dengan rata-rata yaitu dosis $350 \mathrm{mg} / \mathrm{kgBB}$ dengan nilai rerata kreatinin 0, $64 \mathrm{mg} / \mathrm{dL}$ dan rerata ureum $39,68 \mathrm{mg} / \mathrm{dL}$.

Kata Kunci: Kreatinin, ureum, daun sirih merah, streptozotocin

Riwayat artikel: Diterima 6 November 2020, Disetujui 20 Desember 2020

Cara sitasi: Tandi, J., Lalu, R., Nuraisyah, S., Magfirah., Kenta, YS., \& Nobertson, R. (2020). Uji Potensi Nefropati Diabetes Daun Sirih Merah (Piper croatum Ruiz \& Pav) pada Tikus Putih Jantan (Rattus norvegicus). KOVALEN: Jurnal Riset Kimia, 6(3): $239-251$. DOI: https://doi.org/10.22487/kovalen.2020.v6.i3.15323

\section{LATAR BELAKANG}

Kesehatan masyarakat Indonesia pada tahun 2018 menurut hasil riset kesehatan dasar menyatakan bahwa $66,91 \%$ penyakit di Indonesia merupakan penyakit tidak menular dan sisanya merupakan penyakit menular dan masih menjadi ancaman untuk diwaspadai oleh masyarakat Indonesia. Riskesdas 2018 menunjukan prevalensi penyakit tidak menular mengalami kenaikan jika dibandingkan dengan 
Riskesdas 2013, antara lain stroke, kanker, penyakit ginjal, diabetes melitus, dan hipertensi (Kemenkes RI, 2018).

Penyakit ginjal adalah kelainan yang mengenai organ ginjall yang timbul akibat berbagai faktor, misalnya infeksi, tumor, kelainan bawaan, penyakit metabolik dan lainlain. Organ yang sering menderita karena adanya zat-zat yang bersifat toksik adalah ginjal. Peningkatan kadar ureum dan kreatinin merupakan salah satu indikator terjadinya gangguan fungsi ginjal (Kemenkes RI, 2018)

Menurut Riskesdas 2018 prevalensi penyakit ginjal naik dari $2 \%$ menjadi $3,8 \%$. Penyakit ginjal ditandai oleh ketidakmampuan ginjal untuk mengalirkan air lewat glomerulus. Hal ini dapat terjadi karena hilangnya keutuhan glomerulus sendiri serta aliran darah ke ginjal yang tidak memadai. Diantara berbagai hasil pemeriksaan laboratorium, peningkatan kadar ureum dan kreatinin menunjukkan adanya gangguan yang parah pada faal penyaringan glomerrulus (Kemenkes RI, 2018).

Sirih merah (Piper Crocatum Ruiz \& Puv) adalah tanaman obat tradisional kegunaannya mengobati diabetes mellitus, kolesterol, tekanan darah tinggi, asam urat, ginjal dan ambeien dengan cara memakan daunnya (Sudewo, 2007). Berdasarkan hal tersebut telah banyak dilakukan pengujian praklinik untuk melakukan kajian kandungan kimia, serta aktivitas farmakologi dari tanaman ini. Kajian pustaka menunjukkan bahwa Sirih merah merupakan salah satu jenis Pipper yang tersebar di beberapa wilayah di dunia, termasuk Indonesia. Tanaman ini mengandung minyak atsiri, alkaloid, flavonoid tannin-polifenol, steroid, dan senyawa neolignan. Sedangkan pengujian farmakologi menunjukkan bahwa tanaman ini mempunyai aktivitas antiinflamasi, antimikkroba, antifungi, antihiperglikemik, antiproliferasi, dann antioksidan. Sirih merah mempunyai efek sebagai nefroterapi dalam menurunkan kadar ureum dan kreatinin (Hartini \& Wulandari, 2016). Penelitian sebelumnya menyebutkan bahwa ekstrak etil asetat daun pandan wangi berpotensi sebaggai obat herbal anti diabetes dengan aktivitas penghambatan yang berdasarkan hassil GC-MS menunjukkan adanya senyawa aktif antidiabetes pada ekstrak etil asetat daun pandan wangi (Sukandar et al., 2010).

\section{METODE PENELITIAN}

\section{Bahan dan Peralatan}

Bahan yang digunakan yaitu alkohol $70 \%$, aluminium foil, aqua destilata, aqua pro injeksi, asam klorida pekat $\mathrm{P}$, asam klorida $2 \mathrm{~N}$, asam sulfat, betadine, buffer sitrat (asam sitrat dan natrium sitrat), daun sirih merah, etanol $96 \%$, kapas, kertas saring, Kit kreatinin, (asam pikrat dan sodium hidroksida), kit ureum, larutan $\mathrm{NaCl}$ 0,9\%, larutan $\mathrm{FeCl}_{3} 5 \%$, Na-CMC 5\%, natrium sulfat, pakan (pakan standar) pereaksi dragendorf, pereaksi lieberman-bunchard, pereaksi meyer, pereaksi wagner, serbuk magnesium $P$, dan streptozotocin.

Alat yang dipergunakan meliputi ayakan mesh 40, batang pengaduk, Bejana maserasi, blender (sharp), Corong (Pyrex), Cawan porselinn $75 \mathrm{ml}$, Erlenmeyer $50 \mathrm{ml}$ (Pyrex), Photometer 5010 (Roche®), Gelas kimia (Pyrex), Gelas ukur (Pyrex), kannddang hewan uji, Labu ukur (Pyrex), Mortir dan stamper, Pipet tetes, rak tabung reaksi, rotary evaporator, sonde oral, spoit injeksi $3 \mathrm{ml}, 5 \mathrm{ml}$, tabung reaksi, tabung darah, tempat air minum dan makan tikus, timbangan analitik, timbangan kasar, Spektrofotometer UV-Vis evolition 201, dan waterbath. 


\section{Prosedur Penelitian}

\section{Pembuatan larutan suspensi Na CMC 0,5\%}

Natrium carboxy methyl cellulose sebanyak 0,5 gram dimasukkan sedikit demi sedikit kedalam lumpang yang berisi $10 \mathrm{~mL}$ aquades panas sambil digerus hingga homogen, lalu diencerkan dengan seddiktit aquades, selanjutnya dimasukkan ke dalam labu ukur 100 $\mathrm{mL}$. Volume dicukupkan hingga $100 \mathrm{~mL}$ dengan aquades.

\section{Pembuatan suspensi ekstrak daun sirih merah}

Serbuk simplisia daun Sirih merah sebanyak 600 gram dimaserasi menggunakan pelarut etannol $96 \%$ selama 3 hari dengan terus dilakukkan pengadukan berulang. Selanjutnya ekstrak disaring menggunakan kertas saring dan diperoleh filtrat dan residu. Filtrat yang diperoleh selanjutnya dipekatkan menggunakan rotary vacum evaporator dengan suhu $60^{\circ} \mathrm{C}$. Kemudian dilanjutkan dengan penguapan menggunakan waterbath hingga diperoleh ekstrak kental daun sirih merah (Piper crocatum Ruiz \& Pav).

\section{Pembuatan larutan induksi Streptozotocin}

(STZ)

Streptozotocin ditimbang sebanyak 0,32 gram lalu dilarutkan menggunakan citrate-buffer saline dengan $\mathrm{pH}$ 4,5 lalu diinduksikan pada tikus melalui intraperitoneal (ip). Dosis streptozotocin yaitu $40 \mathrm{mg} / \mathrm{kg} \mathrm{BW}$.

\section{Perlakuan hewan uji}

Penggunaan tikus pada penelitian sebanyak 25 ekor tikus yang telah memenuhi kriteria inklusi, selanjutnya hewan uji dibagi dalam 5 kelompok perlakuan. Masing-masing kelompok terdapat 5 ekor tikus putih jantan dan dikandangkan perkelompok perlakuan, diberi pakan standar dan minum. Penelitian dilakukan selama 28 hari terhitung pada saat tikus diadaptasikan selama 2 minggu. Selanjutnya masing-masing kelompok diberian perlakuan sebagai berikut:

a. Penelitian hari ke- 0, kelompok kontrol, kelompok kontrol negatif, kelompok perlakuan I, kelompok perlakuan II, dan kelommpokk perlakuan III, dipuaskan terlebih dahulu kemudian kadar glukosa, ureum, dan kreatinin awal tikus diukur.

b. Selain hewan coba kontrol normal, tikus diinduksi sterptozotocin dosis $40 \mathrm{mg} / \mathrm{kg} \mathrm{BB}$ secara i.p Setelah 1 minggu (hari ke 7) paparan sterptozotocin glukosa, ureum dan kreatinin apakah sterptozotocin telah mempegaruhi metabolisme ureum dan kreatinin.

c. Pengukuran kembali dilanjutkan pada hari ke14, ke 21 dan 28 dengan ini terlebih dahulu dipuasakan. Dimulai dari hari ke-7 tiap-tiap kelompok diberi perlakuan sebagai berikut kontrol normal tanpa induksi diberi suspensi $\mathrm{Na}$ CMC 0,5\% Kontrol negatif. kelompok perlakuan I diberi suspensi ekstrak daun sirih $150 \mathrm{mg} / \mathrm{kg}$, kelompok II ekstrak daun sirih $300 \mathrm{mg} / \mathrm{kg} \mathrm{BB}$, kelompok III diberi suspensi ekstrak daun sirih 600 $\mathrm{mg} / \mathrm{kg}$. BB setiap hari selama 21 hari. Semua sampel darah diambil melalui vena ekor tikus dan ditempatkan di dalam tabung Effendrof.

\section{Analisis ureum}

Alat evolition $201 \quad$ UV-Visible Spectrophotometer untuk mengukur kadar ureum dalam serum darah bekerja secara otomatis (Tandi et al., 2020). Komposisi reagen ureum pertama terdiri dari R1 dan R3. R1 terdiri dari larutan penyangga (buffer fosfat, $\mathrm{pH}: 7,0$ ) $120 \mathrm{mmol} / \mathrm{L}$, natrium salisilat $60 \mathrm{mmol} / \mathrm{L}$ dan EDTA $1 \mathrm{mmol} / \mathrm{L}$ dan $\mathrm{R} 3$ terdiri dari urease $>500$ $\mathrm{KU} / \mathrm{l}$. Reagen kedua (R2) terdiri dari larutan 
penyangga (buffer fosfat, $\mathrm{pH}<13$ ) $120 \mathrm{mmol} / \mathrm{L}$ dan natrium hipoklorit $10 \mathrm{mmol} / \mathrm{L}$. Jumlah serum sampel yang dibutuhkan adalah $10 \mu \mathrm{L}$. Lalu ditambahkan reagen pertama $1000 \mu \mathrm{L}$. Lalu diinkubasi selama 5 menit pada suhu $20-25^{\circ} \mathrm{C}$. Setelah itu, ditambahkan reagen 2 sebanyak $1000 \mu \mathrm{L}$. Diamkan selama 10 menit suhu 20$25^{\circ} \mathrm{C}$, lalu diukur dengan mengunakan Spectrofotometer Uv-Vis pada panjang gelombang $578 \mathrm{~nm}$, ditunggu beberapa saat kemudian dicatat absorban pengukuran kadar ureum dengan rumus.

$$
\text { Kadar Ureum }=\frac{\text { Absorban Sampel }}{\text { Absorban Standar }} \times 80 \mathrm{mg} / \mathrm{dL}
$$

\section{Analisis kreatinin}

Analisis kadar kreatinin mengunakan Spectrofotometer Uv-Vis (Tandi et al., 2020). Jumlah serum yang dibutuhkan adalah $200 \mu \mathrm{L}$, kemudian ditambahkan R1 (Asam Pikrat 26 $\mathrm{mmol} / \mathrm{L} 500 \mu \mathrm{L}$ dan reaggenn $\mathrm{R} 2$ (Natrium hidrosida $1,6 \mathrm{~mol} / \mathrm{L}) 500 \mu \mathrm{L}$, dicampur hingga merata. Diukur pada 30 detik dengan menggunakan Spektrofotometer Uv-Vis evolution 201 pada panjang gelombang $492 \mathrm{~nm}$ untuk mendapatkan nilai absorban pertama (A1) kemudian diamkan kembali selama 2 menit, setelah itu ukur kembali untk mendaptatkan nilai absorban kedua (A2). Kemudian menghitung nilai kadar kreatinin dari nilai asorban tersebut dengan rumus.

$$
\text { Kadar Kreatinin }=\frac{\text { Absorban Sampel }(\mathrm{A} 2-\mathrm{A} 1)}{\text { Absorban Standar }} \times 2 \mathrm{mg} / \mathrm{dL}
$$

\section{Teknik pengumpulan dan analisis data}

Data sampel yang diperoleh berupa kadar glokosa ureum dan kreatinin darah tikus putih jantan sebelum dan sesudah induksi streotozotocin dengan dosis tunggal $40 \mathrm{mg} / \mathrm{kg}$ BB secara i.p dan setelah pemberian ektrak etanol daun sirih merah dengan dosis $150 \mathrm{mg} / \mathrm{kg}$
BB, $250 \mathrm{mg} / \mathrm{kg}$ BB, $350 \mathrm{mg} / \mathrm{kg}$ BB secara peroral setiap hari dihitung dan semua data dianalisis dengan uji normalitas dan uji homogenitas, kemudian menggunakan uji One Way Anova data yang normal dan homogen dan Kuskal Wallis untuk data yang tidak normal dan tidak homogen pada taraf kepercayaaan 95\%. Uji ini digunakan untuk mengetahui perbedaan. Apabila ada perbedaan yang signifikan, maka dilakukan uji lanjut post hoc test LSD untuk one way Annovva dan Mann Whitney untuk kruskal wallis bertujuan mengetahui kelompok perlakuan yang berbeda yang efektif. Data dianalisis mengunakan program SPSS 23.

\section{HASIL DAN PEMBAHASAN}

\section{Komponen Fitokimia Ekstrak Etanol Sirih Merah}

Penelitian ini menggunakan daun sirih merah (Piper crocatum Ruiz \& Pav) yang diperoleh dari kecamatan Mantikulore Kota Palu, Provinsi Sulawesi Tengah. Sebelum penelitian ini dilakukan tanaman terlebih dahulu diidentifikasi di UPT Sumber Daya Hayati Universitas Tadulako Sulawesi Tengah. Identifikasi dilakukan untuk memastikan bahwa jenis daun sirih merah yang digunakan dalam penelitian ini benar adalah spesies Piper crocatum Ruiz \& Pav.

Metode yang digunakan adalah metode maserasi. Alasan menggunakan metode maserasi karena peralatan yang digunakan sederhana, tidak menggunakan pemanasan saat penyarian sehingga mencegah kemungkinan rusaknya senyawa bioaktif yang terdapat pada sampel serta sifat bahan uji yang lunak dan mudah mengembang dalam cairan penyari akan menembus dinding sel dan masuk kedalam rongga sel yang mengandung zat aktif, zat aktif akan larut dan ada nya perbedaan konsentarasi antara larutan zat aktif didalam 
dan diluar sel menyebabkan larutan terpekat keluar hingga terjadi keseimbangan konsentrasi antara larutan didalam dan diluar sel. Pelarut yang digunakan dalam metode maserasi ini adalah etanol 96\%. Ekstrak kental yang diperoleh kemudian dilakukan pemisahan pelarut dengan menggunakan rotari vacum evaporator kemudian dilanjutkan dengan uji penapisan fitokimia untuk mengetahui kandungan senyawa yang terdapat pada ekstrak daun sirih merah. Hasil uji penapisan fitokimia menunjukkan bahwa ekstrak etanol daun sirih merah mengandung senyawa flavonoid, alkaloid, saponin dan tanin (Tabel 1).

Tabel 1. Uji hasil fitokimia ekstrak daun sirih merah

\begin{tabular}{cccc}
\hline \multirow{2}{*}{ Senyawa Bioaktif } & Pereaksi & \multicolumn{2}{c}{ Hasil } \\
\cline { 3 - 4 } & Dragendorf & Terbentuknya endapan merah & + \\
Alkaloid & Magnesium \&HCl & Terbentuknya warna merah & + \\
Flavonoid & Pembentuk busa & Adanya busa terbentuk setinggi lebih $1 \mathrm{~cm}$ & + \\
Saponin & $\mathrm{FeCl}_{3} 1 \%$ & Terbentuknya warna biru kehitaman hitam & + \\
\hline
\end{tabular}

Keterangan: (+) : mengandung golongan senyawa yang di uji

\section{Hasil Analisis Kadar Glukosa}

Tikus uji yang digunakan memiliki kadar glukosa normal yang terlihat pada hari ke-0, yaitu $81,4 \pm 6,02 \mathrm{mg} / \mathrm{dL}$. Kriteria glukosa normal, yaitu pada interval $50-135 \mathrm{mg} / \mathrm{dL}$ (Tandi et al., 2019). Ekstrak etanol daun sirih merah dosis $150 \mathrm{mg} / \mathrm{kgBB}$ merupakan dosis yang efektif dalam menurunkan kadar glukosa darah dengan nilai rata-rata penurunan kadar glukosa darah 238,25 $\mathrm{mg} / \mathrm{dL}$. Hasil menunjukkan bahwa hewan uji telah mengalami hiperglikemia dikarenakan kadar glukosa $>200 \mathrm{mg} / \mathrm{dL}$ pada hari ke-7 (Tabel 2).

Tabel 2.Tabel rerata kadar glukosa darah

\begin{tabular}{cccccccc}
\hline \multirow{2}{*}{$\begin{array}{c}\text { Hari } \\
\text { ke }\end{array}$} & $\begin{array}{c}\text { Kontrol } \\
\text { Normal }\end{array}$ & $\begin{array}{c}\text { Kontrol } \\
\text { Negatif }\end{array}$ & $\begin{array}{c}\text { Kontrol Positif } \\
\text { (Glibenklamid) }\end{array}$ & $\begin{array}{c}\text { Dosis 150 } \\
\mathrm{mg} / \mathrm{kgBB}\end{array}$ & $\begin{array}{c}\text { Dosis 250 } \\
\mathrm{mg} / \mathrm{kgBB}\end{array}$ & $\begin{array}{c}\text { Dosis } 350 \\
\mathrm{mg} / \mathrm{kgBB}\end{array}$ & $\mathrm{P}$ \\
\hline 0 & $81.4 \pm 6.02$ & $81.2 \pm 11.58$ & $84.8 \pm 12.13$ & $82 \pm 6.85$ & $76.4 \pm 5.02$ & $53 \pm 5.24$ & 0.724 \\
7 & $81.8 \pm 6.22$ & $390.4 \pm 57.12$ & $525 \pm 60.07$ & $409.8 \pm 41.93$ & $429.6 \pm 65.7$ & $469.8 \pm 56.41$ & 0.000 \\
14 & $79 \pm 5.91$ & $396.8 \pm 56.05$ & $325.8 \pm 59.75$ & $314.4 \pm 53.24$ & $443 \pm 30.11$ & $424.6 \pm 71.06$ & 0.000 \\
21 & $79.8 \pm 6.37$ & $391.4 \pm 43.63$ & $209 \pm 43.77$ & $249.8 \pm 39.8$ & $323.8 \pm 55.02$ & $304.6 \pm 78.91$ & 0.000 \\
28 & $80.6 \pm 4.15$ & $399 \pm 53.93$ & $103.8 \pm 40.6$ & $161.4 \pm 12.64$ & $184.6 \pm 28.47$ & $226.6 \pm 104.98$ & 0.000 \\
\hline
\end{tabular}

Dosis $150 \mathrm{mg} / \mathrm{kgBB}$ menghasilkan penurunan glukosa yang mendekati nilai normal (Gambar 1). Hal serupa juga didapatkan oleh (Tandi et al., 2019), yaitu ekstrak Daun Afrika dapat menurunkan kadar glukosa pada tikus uji pada dosis $150 \mathrm{mg} / \mathrm{kgBB}$ hingga pada nilai $115,4 \mathrm{mg} / \mathrm{dL}$. 


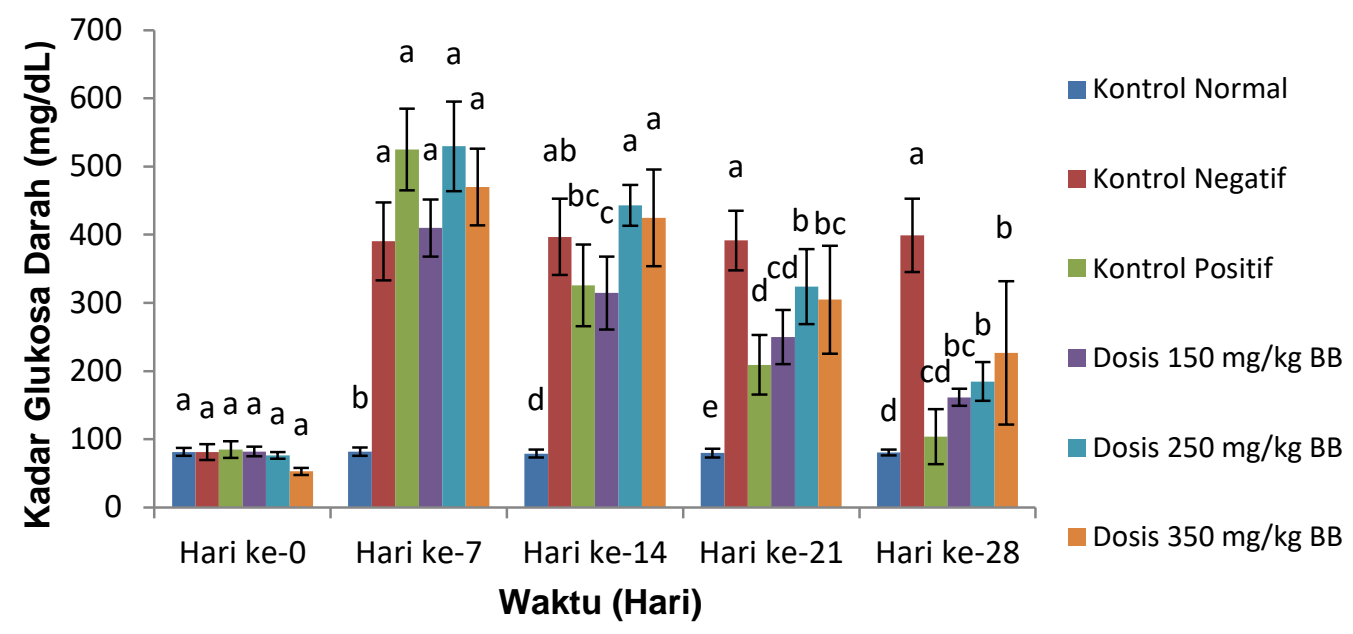

Gambar 1. Hasil analisis kadar glukosa

\section{Hasil Analsis Kadar Kreatin}

Pemberian perlakuan sesuai kelompok dilakukan selama 28 hari. Pengujian ekstrak etanol daun sirih merah terhadap kadar kreatinin dan ureum digunakan uji praklinik menggunakan 25 ekor tikus putih jantan yang dibagi dalam 5 kelompok perlakuan dan masingmasing kelompok terdapat 5 ekor tikus. Kelompok terdiri dari kelompok kontrol normal, kelompok kontrol negatif yang diinduksi dan diberi suspensi $\mathrm{Na} \mathrm{CMC}$ 0,5\%. Kontrol normal merupakan kontrol yang menjadi tolak ukur nilai normal pada pengujian, sedangkan kontrol negatif merupakan tolak ukur kerusakan yang terjadi oleh pengaruh pemberian streptozotocin. Kelompok perlakuan yang diinduksi dan diberikan ekstrak etanol daun sirih merah dosis $150 \mathrm{mg} / \mathrm{kg}$ BB, kelompok perlakuan yang diinduksi dan diberikan ekstrak etanol sirih merah dosis $250 \mathrm{mg} / \mathrm{kg}$ BB, dan kelompok perlakuan yang diinduksi dan diberikan ekstrak etanol sirih merah dosis $350 \mathrm{mg} / \mathrm{kg}$ BB. Pemberian ekstrak sesuai kelompok dilakukan selama 21 hari. Pengukuran kadar kreatinin dan ureum dilakukan setiap 7 hari/minggu.

Pengukuran kadar kreatinin dan ureum dilakukan sebanyak 5 kali yaitu hari ke-0, 7, 14, 21, 28. Data hasil pengukuran kadar kreatinin dan ureum tikus putih jantan yang diperoleh terlebih dahulu dianalisis dengan uji normalitas dan uji homogenitas, apabila distribusi data normal dan homogen, maka analisis data dilakukan dengan analisis One Way Anova, jika terdapat perbedaan maka dilanjutkan dengan uji lanjut post hoc LSD.

Penelitian ini dilakukan untuk mengetahui kadar kreatinin awal sebelum perlakuan, Pada hari ke 0 diperoleh data rerata kadar kreatinin (mg/dL BB) untuk kelompok normal, kelompok negatif, kelompok ekstrak dosis $150 \mathrm{mg} / \mathrm{kg} \mathrm{BB}$, kelompok ekstrak dosis $250 \mathrm{mg} / \mathrm{kg}$ BB, dan kelompok ekstrak dosis $350 \mathrm{mg} / \mathrm{kg}$ BB bertutrutturut adalah 0,$58 ; 0,50 ; 0,47 ; 0,49 ; 0,56,(\mathrm{mg} / \mathrm{dL})$ yang menandakan kadar kreatinin awal tikus putih jantan berada dinilai normal (Gambar 2). Kadar normal kreatinin tikus adalah 0,2-0,8 $\mathrm{mg} / \mathrm{dL}$. Hasil uji statistik One Way Anova hari ke 0 menunjukkan bahwa semua kelompok berbeda tidak signifikan pada kadar kreatinin awal hewan uji yang di tandai dengan nilai $p>$ 0,05 (nilai $p=0,223$ ). Artinya kadar kreatinin pada awal penelitian dalam keadaan homogen.

Hari ke-7 dilakukan pengukuran setelah induksi streptozotocin. Berdasarkan Tabel 3, terlihat kadar rerata kreatinin mengalami peningkatan pada semua kelompok kecuali 
kelompok normal yang tidak diinduksi streptozotocin. Hasil uji statistik One Way Anova menunjukkan perbedaan yang signifikan ditandai dengan nilai $p<0,05$ (nilai $p=0,000$ ) artinya terdapat perbedaan yang signifikan dari semua kelompok percobaan sehingga dilanjutkan dengan uji lanjut post hoc LSD. Hasil uji lanjut Post hoc LSD menunjukkan bahwa dosis $150 \mathrm{mg} / \mathrm{kg}$ BB berbeda signifikkan dengan kontrol normal artinya hewan uji pada kelompok perlakuan dalam keadaan sakit yang disebabkan oleh pemberian induksi streptozotocin dapat menyebabkan kerusakan metabolisme pada ginjal yang dapat mengakibatkan penurunan fungsi filtrasi ginjal sehingga kadar kreatinin dalam darah akan meningkat. Berbeda tidak signifikan dengan kontrol negatif artinya induksi dari streptozotocin $40 \mathrm{mg} / \mathrm{kg}$ BB tersebut berefek.

Tabel 3.Tabel rerata kadar kreatinin

\begin{tabular}{ccccccc}
\hline & \multicolumn{7}{c}{ Rerata \pm SE Kadar Kreatinin (mg/dl) } \\
\cline { 2 - 7 } Hari ke- & Kontrol Normal & $\begin{array}{c}\text { Kontrol } \\
\text { Negatif }\end{array}$ & $\begin{array}{c}\text { Dosis 150 } \\
\mathrm{mg} / \mathrm{kg} \mathrm{BB}\end{array}$ & $\begin{array}{c}\text { Dosis 250 } \\
\mathrm{mg} / \mathrm{kg} \mathrm{BB}\end{array}$ & $\begin{array}{c}\text { Dosis 350 } \\
\mathrm{mg} / \mathrm{kg} \mathrm{BB}\end{array}$ & $\mathrm{P}$ \\
\hline 0 & $0,58 \pm 0,09$ & $0,5 \pm 0,07$ & $0,47 \pm 0,21$ & $0,49 \pm 0,15$ & $0,56 \pm 0,09$ & 0,223 \\
7 & $0,48 \pm 0,19$ & $1,31 \pm 0,11$ & $1,43 \pm 0,14$ & $1,45 \pm 0,20$ & $1,24 \pm 0,15$ & 0,000 \\
14 & $0,48 \pm 0,09$ & $1,37 \pm 0,09$ & $1,21 \pm 0,14$ & $1,05 \pm 0,04$ & $1,02 \pm 0,07$ & 0,000 \\
21 & $0,56 \pm 0,13$ & $1,24 \pm 0,13$ & $1,03 \pm 0,10$ & $0,96 \pm 0,04$ & $0,93 \pm 0,07$ & 0,000 \\
28 & $0,54 \pm 0,05$ & $1,35 \pm 0,09$ & $0,85 \pm 0,07$ & $0,86 \pm 0,06$ & $0,64 \pm 0,07$ & 0,000 \\
\hline
\end{tabular}

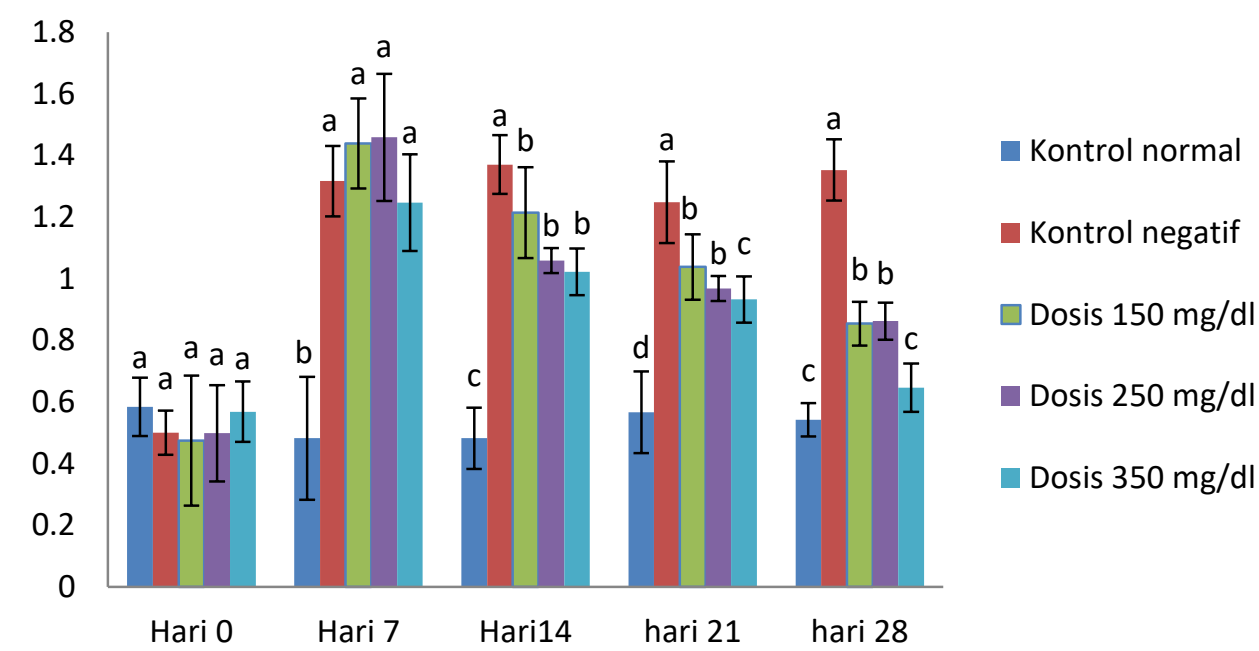

Gambar 2. Hasil analisis kadar kreatin

Dosis $250 \mathrm{mg} / \mathrm{kg}$ berbeda signifikan dengan kontrol normal yang disebabkan oleh pemberian induksi streptozotocin dapat menyebabkan kerusakan metabolisme pada ginjal yang dapat mengakibatkan penurunan fungsi filtrasi ginjal sehingga kadar kreatinin dalam darah akan meningkat. Berbeda tidak signifikan dengan kontrol negatif artinya induksi dari streptozotocin $40 \mathrm{mg} / \mathrm{kg}$ BB tersebut berefek. 
Dosis $350 \mathrm{mg} / \mathrm{kg}$ berbeda signifikan dengan kontrol normal yang disebabkan oleh pemberian induksi streptozotocin dapat menyebabkan kerusakan metabolisme pada ginjal yang dapat mengakibatkan penurunan fungsi filtrasi ginjal sehingga kadar kreatinin dalam darah akan meningkat. Berbeda tidak signifikan dengan kontrol negatif artinya induksi dari streptozotocin $40 \mathrm{mg} / \mathrm{kg}$ BB tersebut berefek.

Hari ke-14 dilakukan pengukuran kadar kreatinin setelah induksi ekstrak. Berdasarkan Tabel 3, kadar kreatinin telah mengalami penurunan. Hasil ui statistik One Way Anova menunjukkan perbedaan yang signifikan semua kelompok perlakuan yang ditandai dengan nilai $p<0,05$ (nilai $p=0,000$ ) sehingga dilanjutkan dengan uji lanjut post hoc $L S D$. Hasil uji lanjut Post hoc LSD menunjukkan bahwa dosis 150 $\mathrm{mg} / \mathrm{kg}$ BB, Dosis $250 \mathrm{mg} / \mathrm{kg}$ Dosis $350 \mathrm{mg} / \mathrm{kg}$ BB berbeda signifikan dengan kontrol normal artinya ekstrak etanol daun sirih merah belum efektif dalam menurunkan kadar kreatinin. Berbeda signifikan dengan kontrol negatif artinya ekstrak etanol daun sirih merah dapat memberikan efek terhadap penurunan kadar kreatinin.

Pada hari ke-21 kadar kreatinin kembali mengalami penurunan (Tabel 3). Hasil ui statistik One Way Anova menunjukkan perbedaan yang signifikan semua kelompok perlakuan yang ditandai dengan nilai $\mathrm{p}<0,05$ (nilai $\mathrm{p}=0,000$ ) sehingga dilanjutkan dengan uji lanjut post hoc $L S D$. Hasil uji lanjut Post hoc $L S D$ menunjukkan bahwa dosis $150 \mathrm{mg} / \mathrm{kg} \mathrm{BB}$, Dosis $250 \mathrm{mg} / \mathrm{kg}$ dan Dosis $350 \mathrm{mg} / \mathrm{kg}$ BB berbeda signifikan dengan kontrol normal artinya ekstrak etanol daun sirih merah telah memberikan efek tetapi belum efektif dalam menurunkan kadar kreatinin. Berbeda signifikan dengan kontrol negatif artinya ekstrak etanol daun sirih merah dapat memberikan efek terhadap penurunan kadar kreatinin. Adapun untuk menentukan dosis yang efektif antara kelompok variasi dosis peneliti melanjutkan pemberian ekstrak dan pengukuran pada minggu berikutnya.

Hari ke-28, kadar kreatinin juga mengalami penurunan (Tabel 3). Hasil ui statistik One Way Anova menunjukkan perbedaan yang signifikan semua kelompok perlakuan yang ditandai dengan nilai $p<0,05$ (nilai $p=0,000$ ) sehingga dilanjutkan dengan uji lanjut post hoc $L S D$. Hasil uji lanjut Post hoc LSD menunjukkan bahwa dosis $350 \mathrm{mg} / \mathrm{kg}$ berbeda signifikan dengan dosis Dosis $150 \mathrm{mg} / \mathrm{kg}$ dan Dosis $250 \mathrm{mg} / \mathrm{kg} \mathrm{BB}$. artinya dosis $350 \mathrm{mg} / \mathrm{kg}$ BB lebih baik dalam menurunkan kadar kreatinin. Berbeda siginikan dengan kontrol negatif artinya ekstrak etanol daun sirih merah pada dosis $350 \mathrm{mg} / \mathrm{kg}$ dapat memberikan efek terhadap penurunan kadar kreatinin. Berbeda tidak signifikan dengan kontrol normal artinya dosis $350 \mathrm{mg} / \mathrm{kg}$ BB sudah mendekati nilai normal.

Hasil pengukuran pada hari ke-28 (setelah pemberian ekstrak) kadar kreatinin pada masing masing kelompok variasi dosis yaitu dosis 150, 250, $350 \mathrm{mg} / \mathrm{kg}$ BB menunjukan penurunan kadar kreatinin dan dosis yang paling efektif adalah dosis 350 $\mathrm{mg} / \mathrm{kg}$ BB. Adapun pemilihan dosis ini karena merupakan yang tertinggi dan paling mendekati nilai normal dalam memberikan efek penurunan kadar kreatinin.

\section{Hasil Analisis Kadar Ureum}

Penelitian juga dilakukan untuk mengetahui kadar ureum awal sebelum perlakuan. Pada hari ke-0 diperoleh data rerata kadar ureum $(\mathrm{mg} / \mathrm{dL} \mathrm{BB})$ rerata kadar ureum (mg/dL) untuk kelompok normal, 
kelompok negatif, kelompok ekstrak dosis 150 $\mathrm{mg} / \mathrm{kg} \mathrm{BB}$, kelompok ekstrak dosis $250 \mathrm{mg} / \mathrm{kg}$ $\mathrm{BB}$, dan kelompok ekstrak dosis $350 \mathrm{mg} / \mathrm{kg} \mathrm{BB}$ bertutrut-turut adalah 33,$02 ; 32,13 ; 31,71$; 33,$26 ; 33,12$, (mg/dL) yang menandakan kadar ureum awal tikus putih jantan berada di atas nilai normal (Gambar 3). Kadar normal ureum tikus adalah 15,0-21,8 mg/dL. Kadar ureum yang tinggi pada semua kelompok perlakuan diakibatkan oleh pemberian pakan yang mengandung protein tinggi, dimana makanan dengan protein yang tinggi akan mempengaruhi distribusi asam amino dalam darah sehingga mempengaruhi kadar ureum. Hasil uji statistik One Way Anova hari ke 0 menunjukkan bahwa semua kelompok berbeda tidak signifikan pada kadar ureum awal hewan uji yang di tandai dengan nilai $p>$ 0,05 (nilai $p=0,806$ ). Hal ini menunjukkan bahwa kadar kreatinin pada awal penelitian dalam keadaan homogen.

Hari ke-7 dilakukan pengukuran setelah induksi streptozotocin. Berdasarkan Tabel 4, terlihat kadar rerata ureum mengalami peningkatan pada semua kelompok kecuali kelompok normal yang tidak diinduksi streptozotocin. Hasil uji statistik One Way Anova menunjukkan perbedaan yang signifikan ditandai dengan nilai $\mathrm{p}<0,05$ (nilai $p=0,000$ ) artinya terdapat perbedaan yang signifikan dari semua kelompok percobaan sehingga dilanjutkan dengan uji lanjut post hoc LSD. Hasil uji lanjut Post hoc LSD menunjukkan bahwa dosis $150 \mathrm{mg} / \mathrm{kg}$ BB berbeda signifikkan dengan kontrol normal artinya hewan uji pada kelompok perlakuan dalam keadaan sakit yang disebabkan oleh pemberian induksi streptozotocin dapat menyebabkan kerusakan metabolisme pada ginjal yang dapat mengakibatkan penurunan fungsi filtrasi ginjal sehingga kadar ureum dalam darah akan meningkat. Berbeda tidak signifikan dengan kontrol negatif artinya induksi dari streptozotocin $40 \mathrm{mg} / \mathrm{kg}$ BB tersebut berefek.

Dosis $250 \mathrm{mg} / \mathrm{kg}$ berbeda signifikan dengan kontrol normal yang disebabkan oleh pemberian induksi streptozotocin dapat menyebabkan kerusakan metabolisme pada ginjal yang dapat mengakibatkan penurunan fungsi filtrasi ginjal sehingga kadar ureum dalam darah akan meningkat. Berbeda tidak signifikan dengan kontrol negatif artinya induksi dari streptozotocin $40 \mathrm{mg} / \mathrm{kg}$ BB tersebut berefek.

Tabel 4. Tabel rerata kadar ureum

\begin{tabular}{ccccccc}
\hline \multirow{2}{*}{ Hari ke- } & \multicolumn{5}{c}{ Rerata kadar ureum Tikus Putih } \\
\cline { 2 - 7 } & Kontrol normal & kontrolnegatif & Dosis 150 & Dosis 250 & Dosis 350 & $P$ \\
\hline 0 & $33,02 \pm 2,5$ & $32,13 \pm 2,02$ & $31,71 \pm 2,21$ & $33,26 \pm 2,78$ & $33,12 \pm 3,46$ & 0,806 \\
7 & $30,24 \pm 5,76$ & $90,40 \pm 9,82$ & $85,92 \pm 2,72$ & $91,06 \pm 2,33$ & $87,07 \pm 7,44$ & 0,000 \\
14 & $29,19 \pm 2,99$ & $91,30 \pm 8,39$ & $75,83 \pm 3,21$ & $78,63 \pm 8,92$ & $74,8 \pm 6,77$ & 0,000 \\
21 & $30,24 \pm 7,52$ & $92,16 \pm 6,54$ & $66,02 \pm 2,02$ & $64,99 \pm 4,41$ & $54,86 \pm 2,03$ & 0,000 \\
28 & $35,49 \pm 5,08$ & $95,20 \pm 4,48$ & $55,47 \pm 2,04$ & $52,17 \pm 1,22$ & $39,68 \pm 8,95$ & 0,000 \\
\hline
\end{tabular}




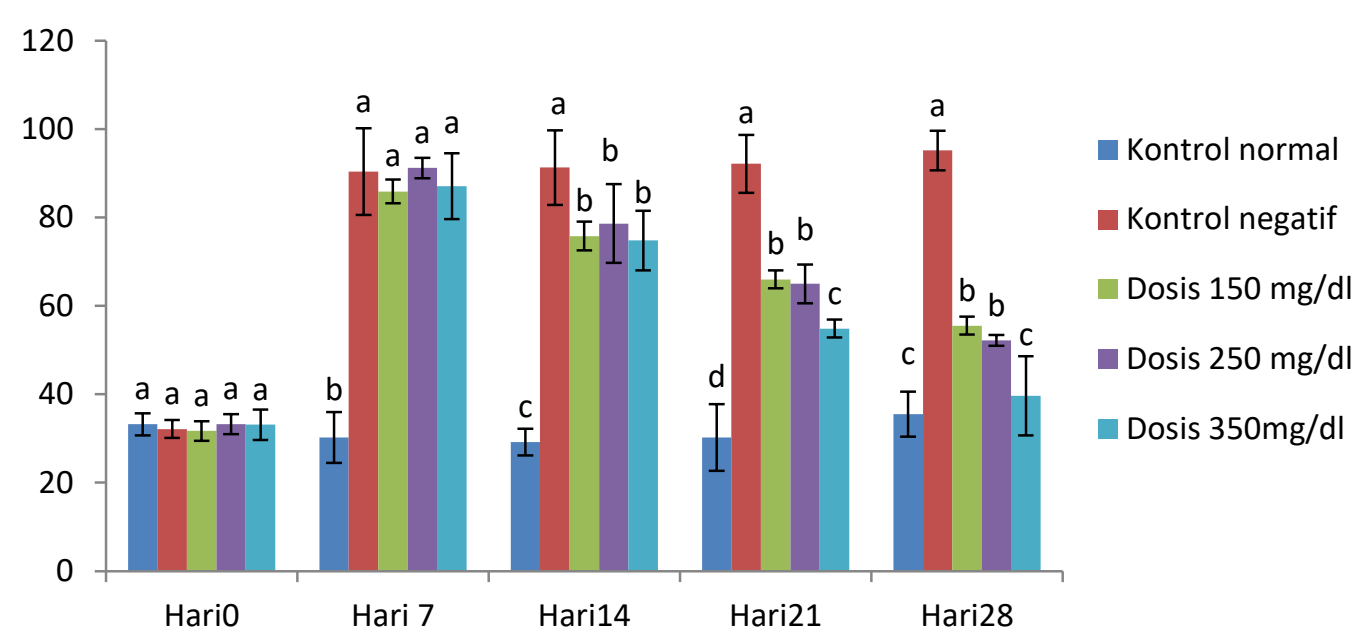

Gambar 3. Hasil analisis kadar ureum

Dosis $350 \mathrm{mg} / \mathrm{kg}$ berbeda signifikan dengan kontrol normal yang disebabkan oleh pemberian induksi streptozotocin dapat menyebabkan kerusakan metabolisme pada ginjal yang dapat mengakibatkan penurunan fungsi filtrasi ginjal sehingga kadar ureum dalam darah akan meningkat. Berbeda tidak signifikan dengan kontrol negatif artinya induksi dari streptozotocin $40 \mathrm{mg} / \mathrm{kg}$ BB tersebut berefek.

Pada hari ke-14 kadar ureum telah mengalami penurunan (Tabel 4). Hasil ui statistik One Way Anova menunjukkan perbedaan yang signifikan semua kelompok perlakuan yang ditandai dengan nilai $p<0,05$ (nilai $\mathrm{p}=0,000$ ) sehingga dilanjutkan dengan uji lanjut post hoc LSD. Hasil uji lanjut Post hoc $L S D$ menunjukkan bahwa dosis $150 \mathrm{mg} / \mathrm{kg} \mathrm{BB}$, Dosis $250 \mathrm{mg} / \mathrm{kg}$ Dosis $350 \mathrm{mg} / \mathrm{kg}$ BB berbeda signifikan dengan kontrol normal artinya ekstrak etanol daun sirih merah belum efektif dalam menurunkan kadar ureum. Berbeda signifikan dengan kontrol negatif artinya ekstrak etanol daun sirih merah dapat memberikan efek terhadap penurunan kadar ureum.

Hari ke-2, kadar ureum masih mengalami penurunan (Tabel 4). Hasil ui statistik One Way Anova menunjukkan perbedaan yang signifikan semua kelompok perlakuan yang ditandai dengan nilai $\mathrm{p}<0,05$ (nilai $\mathrm{p}=0,000$ ) sehingga dilanjutkan dengan uji lanjut post hoc $L S D$. Hasil uji lanjut Post hoc LSD menunjukkan bahwa dosis $150 \mathrm{mg} / \mathrm{kg} \mathrm{BB}$, Dosis $250 \mathrm{mg} / \mathrm{kg}$ dan Dosis $350 \mathrm{mg} / \mathrm{kg}$ BB berbeda signifikan dengan kontrol normal artinya ekstrak etanol daun sirih merah telah memberikan efek tetapi belum efektif dalam menurunkan kadar ureum. Berbeda signifikan dengan kontrol negatif artinya ekstrak etanol daun sirih merah dapat memberikan efek terhadap penurunan kadar ureum. Adapun untuk menentukan dosis yang efektif antara kelompok variasi dosis peneliti melanjutkan pemberian ekstrak dan pengukuran pada minggu berikutnya.

Hasil pengukuran pada hari ke-28 menunjukkan kadar ureum pada hewan uji kembali mengalami penurunan (Tabel 4). Hasil ui statistik One Way Anova menunjukkan perbedaan yang signifikan semua kelompok perlakuan yang ditandai dengan nilai $p<0,05$ (nilai $\mathrm{p}=0,000$ ) sehingga dilanjutkan dengan uji lanjut post hoc LSD. Hasil uji lanjut Post hoc LSD menunjukkan bahwa dosis $350 \mathrm{mg} / \mathrm{kg}$ berbeda signifikan dengan dosis Dosis 150 $\mathrm{mg} / \mathrm{kg}$ dan Dosis $250 \mathrm{mg} / \mathrm{kg}$ BB. artinya dosis 
$350 \mathrm{mg} / \mathrm{kg}$ BB lebih baik dalam menurunkan kadar ureum. Berbeda siginikan dengan kontrol negatif artinya ekstrak etanol daun sirih merah pada dosis $350 \mathrm{mg} / \mathrm{kg}$ dapat memberikan efek terhadap penurunan kadar ureum. Berbeda tidak signifikan dengan kontrol normal artinya dosis $350 \mathrm{mg} / \mathrm{kg}$ BB sudah mendekati nilai normal.

Hasil pengukuran pada hari ke-28 (setelah pemberian ekstrak) kadar ureum pada masing masing kelompok variasi dosis yaitu dosis 150 , 250, $350 \mathrm{mg} / \mathrm{kg}$ BB menunjukan penurunan kadar ureum dan dosis yang paling efektif adalah dosis $350 \mathrm{mg} / \mathrm{kg}$ BB. Adapun pemilihan dosis ini karena merupakan yang tertinggi dan paling mendekati nilai normal dalam memberikan efek penurunan kadaru ureum.

Adanya efek terhadap penurunan kreatinin dan ureum oleh ekstrak etanol daun sirih merah karena mengandung senyawa metabolit sekunder yaitu alkaloid, flavonoid, saponin, dan tanin. Flavonoid berperan sebagai antioksidan yang mampu mengurangi stress oksidatif dengan cara mencegah terjadinya rantai pengubahan superoksida menjadi hydrogen superoksida dengan mendonorkan atom hydrogen dari kelompok aromatic hidroksil ($\mathrm{OH})$ untuk mengikat radikal bebas dan membuangnya dari dalam tubuh melalui sistem ekskresi (Redha, 2010).

Hasil perbandingan dengan penelitian terdahulu yaitu pada ekstrak etanol daun gendola merah $200 \mathrm{mg} / \mathrm{kg}$ BB efektif dalam menurunkan kadar ureum dan kreatinin dengan nilai rata-rata kreatinin $0,61 \mathrm{mg} / \mathrm{dL}$ dan ureum 29,48 mg/ dL (Tandi et al., 2017a). Uji efek ekstrak etanol daun gedi merah pada dosis 100 $\mathrm{mg} / \mathrm{kg}$ BB efektif dalam menurunkan kadar ureum dan kreatinin dengan rata-rata kreatinin $0,56 \mathrm{mg} / \mathrm{dL}$ dan ureum $38,0 \mathrm{mg} / \mathrm{dL}$ (Tuldjannah et al., 2018). Jika dibandingkan dengan penelitian ekstrak etanol daun sirih merah pada dosis $350 \mathrm{mg} / \mathrm{kg}$ BB dengan nilai $0,64 \mathrm{mg} / \mathrm{dL}$ dan 39,6 mg/dL tidak lebih baik dari pada penelitian terdahulu karena memiliki selisih kadar kreatinin sebesar $0,03 \mathrm{mg} / \mathrm{dL}$ dan ureum $10,12 \mathrm{mg} / \mathrm{dL}$ dengan ekstrak etanol daun gedi merah, selisih kadar kreatinin sebesar 0,08 $\mathrm{mg} / \mathrm{dL}$ dan ureum 1,6 mg/dL. Hal ini disebabkan karena tingkat kandungan senyawa metabolit sekunder yaitu flavonoid, alkaloid, taninpolifenol steroid-terpenoid, dan saponin antioksidan dari daun sirih merah lebih rendah dibandingkan dengan daun gedi merah dan daun gendola merah sehingga pada dosis efektif mencapai sel target lebih baik daun gendola merah (Tandi et al., 2017a) dan gedi merah (Tandi et al., 2017b) dalam memperbaiki sel $\beta$ pankreas. Sedangkan Ekstrak etanol daun jambu air pada dosis $100 \mathrm{mg} / \mathrm{kg}$ BB efektif dalam menurunkan kadar ureum dan kreatinin dengan rata-rata kreatinin $0,74 \mathrm{mg} / \mathrm{dL}$ dan ureum 44,1 mg/dL (Tandi, 2017). Jika dibandingkan dengan penelitian ekstrak etanol daun sirih merah pada dosis $350 \mathrm{mg} / \mathrm{kg}$ BB dengan nilai $0,64 \mathrm{mg} / \mathrm{dL}$ dan $39,6 \mathrm{mg} / \mathrm{dL}$ lebih baik dari pada penelitian terdahulu karena memiliki selisih kadar kreatinin sebesar 0,1 $\mathrm{mg} / \mathrm{dL}$ dan ureum $4,5 \mathrm{mg} / \mathrm{dL}$ Hal ini disebabkan karena tingkat kandungan senyawa metabolit sekunder yaitu flavonoid, alkaloid, taninpolifenol steroid-terpenoid, dan saponin antioksidan pada daun sirih merah lebih baik dari daun jambu air dalam memperbaiki sel $\beta$ pankreas.

Tipe antioksidan berdasarkan kelarutannya terdiri dari antioksidan lipofilik (larut dalam non polar) dan antioksidan hidrofilik (larut dalam polar). Flavonoid merupakan senyawa polar karena memiliki gula yang terikat. Oleh karena 
itu, flavonoid cenderung larut dalam pelarut polar. Antioksidan hidrofilik memiliki kemampuan yang kuat dalam melindungi sistem biologis dan mengurangi kerusakan yang disebabkan oleh reactive oxygen species (ROS). Flavonoid merupakan senyawa pereduksi yang baik, mekanisme antioksidan dari flavonoid adalah mampu menangkal radikal bebas (ROS/Reactive Oxygen Species atau RNS/Reactive Nitrogen Species) melalui transfer electron serta menghambat reaksi peroksidasi, mencegah regenerasi reactive oxygen species (ROS), dan secara tidak langsung dapat meningkatkan aktivitas antioksidan enzim (Hardiningtyas et al., 2014). Pencegahan terbentuknya reactive oxygen species (ROS) oleh flavonoid dilakukan dengan beberapa cara yaitu menghambat kerja enzim xantin oksidase dan Nycotinamide Adenine Dinucleotide Phosphate (NAPDH) sehingga dapat mencegah reaksi redoks yang dapat menghasilkan radikal bebas (Tandi et al., 2020). Flavonoid juga diketahui mampu bekerja secara langsung terhadap sel $\beta$ pankreas, dengan memicu pengaktifan kaskade signal Camp dalam memperkuat sekresi insulin yang disensitisasi oleh glukosa. Antioksidan diketahui dapat mencegah kerusakan sel $\beta$ pankreas karena memiliki aktivitas dengan cara menangkap atau menetralkan radikal bebas terkait dengan gugus - $\mathrm{OH}$ fenolik sehingga dapat memperbaiki keadaan jaringan yang rusak (Zahra et al., 2017).

\section{KESIMPULAN}

Berdasarkan hasil penelitian dapat disimpulkan bahwa ekstrak etanol daun sirih merah (Piper crocatum Ruiz \& Pav) mengandung senyawa metabolit sekunder antara lain flavonoid, alkaloid, saponin dan tanin. Ekstrak etanol daun sirih merah memiliki potensi dalam menurunkan kadar kreatinin dan ureum pada tikus putih jantan yangg diinduksi streptozotocin. Ekstrak etannol Daun Sirih Merah dosis $350 \mathrm{mg} / \mathrm{kg}$ efektif terhadap penurunan kadar ureum dan kreatinin dengan rata rata kreatinin 0,64 $\mathrm{mg} / \mathrm{dL}$ dan ureum 39,6 $\mathrm{mg} / \mathrm{dL}$.

\section{DAFTAR PUSTAKA}

Hardiningtyas, S., Purwaningsih, S., \& Handharyani, E. (2014). Aktivitas Antioksidan Dan Efek Hepatoprotektif Daun Bakau Api-Api Putih. JPHPI, 17(1): 80-91.

Hartini, Y., \& Wulandari, E. (2016). Buku Panduan Praktikum Farmakologi Fitokimia. Fakultas Farmasi Universitas Sanata Dharma, Depok.

Kemenkes RI. (2018). Hasil Utama Riskesdas 2018. Kementerian Kesehatan RI, Jakarta.

Redha, A. (2010). Flavonoid: Struktur, Sifat Antioksidatif dan Peranannya Dalam Sistem Biologis. Jurnal Teknologi Pertanian Politeknik Negri Pontianak, 9(2): 196-202.

Sudewo, B. (2007). Basmi Penyakit dengan Sirih Merah. PT Agromedia Pustaka, Jakarta.

Sukandar, D., Hermanto, S., \& Mabrur, I. A. (2010). Aktivitas Senyawa Antidiabetes Ektrak Etil Asetat Daun Pandan Wangi (Pandanus Amaryllifolius Roxb.). Jurnal Kimia Valensi, 1(6). https://doi.org/10.15408/jkv.v1i6.238

Tandi, J. (2017). Pengaruh Ekstrak Etanol Daun Jambu Air (Syzygium aqueum (Burm f.)Alston) terhadap Glukosa Darah, Ureum dan Kreatinin Tikus Putih (Rattus norvegicus). Journal of Tropical Pharmacy and Chemistry, 4(2): 43-51. https://doi.org/10.25026/jtpc.v4i2.137

Tandi, J., Wulandari, A., \& Asrifa, A. (2017a). Efek Ekstrak Etanol Daun Gendola Merah (Basella alba L.) terhadap Kadar Kreatinin, Ureum dan Deskripsi Histologis Tubulus Ginjal Tikus Putih Jantan (Rattus norvegicus) Diabetes yang Diinduksi Streptozotocin: Jurnal Farmasi Galenika (Galenika Journal of Pharmacy) (e- 
Journal), $\quad 3(2): \quad$ 93-102. https://doi.org/10.22487/j24428744.0.v0.i0. 8813

Tandi, J., Roem, M., \& Yuliet, Y. (2017b). Efek Nefroprotektif Kombinasi Ekstrak Daun Gedi Merah dan Daun Kumis Kucing pada Tikus Induksi Etilen Glikol. Journal of Tropical Pharmacy and Chemistry, 4(1): 27-34. https://doi.org/10.25026/jtpc.v4i1.129

Tandi, J., Mariani, N. M. I., \& Setiawati, N. P. (2019). Potensi Ekstrak Etanol Daun Afrika (Gymnanthemum amygdalinum (Delile) Sch. Bip, Ex walp) Terhadap Penurunan Kadar Glukosa Darah dan Histopatologi Pankreas Tikus Putih Jantan (Rattus norvegicus) yang Diinduksi Streptocotocin dan Pakan Tinggi Lemak. Majalah Farmasetika, 4(Suppl1): 66-77. https://doi.org/10.24198/mfarmasetika.v4i0 .25861

Tandi, J., Muttaqin, H. K., Handayani, K. R., Mulyani, S., \& Patala, R. (2020). Uji Potensi Metabolit Sekunder Ekstrak Kulit Buah Petai (Parkia speciosa Hassk) terhadap Kadar Kreatinin dan Ureum Tikus Secara Spektrofotometri UV-Vis: KOVALEN: Jurnal Riset Kimia, 6(2): 143-151. https://doi.org/10.22487/kovalen.2020.v6.i 2.15225

Tuldjannah, M., Tadjio, Y. K., \& Tandi, J. (2018). Efek Nefroprotektif Ekstrak Daun Gedi Merah Terhadap Kadar Kreatinin/Ureum Tikus Putih Jantan Diinduksi Etilenglikol. Farmakologika: Jurnal Farmasi, 15(2): 160-167.

Zahra, F., Budhiarta, A. A. G., \& Pangkahila, W. (2017). Pemberian ekstrak daun cincau (Mesona palustris $\mathrm{BL}$ ) oral meningkatkan jumlah sel $\beta$ pankreas dan menurunkan gula darah puasa pada tikus putih (Rattus norvegicus) jantan galur Wistar diabetes. EBiomedik, $5(1)$. https://doi.org/10.35790/ebm.5.1.2017.150 34 